\title{
Impact of Dividend Policy on the Market Value of the Company
}

\author{
Ivan Eryomin ${ }^{1, *}$, Olga Likhacheva $^{1}$, and Lyudmila Chernikova ${ }^{1}$ \\ ${ }^{1}$ Financial University under the Government of the Russian Federation, Moscow, Russia
}

\begin{abstract}
The article is devoted to the analysis and assessment of the impact of dividends on the market value of the company. The study is based on data from company reports and statistics from the Moscow Exchange. This paper presents a regression analysis of a choice consisting of 1) 20 systems of Russian companies and 2) 5 largest companies in the oil and gas sector for the period 2013-2019. The regression results show that dividends have a positive effect on capitalization only if the policy is based on the residual principle. The conclusions made in the work, which provide recommendations and a statistical assessment of dependence, can find practical application in determining the dividend policy of an organization and predicting changes in the capitalization of companies.

Keywords: dividend policy, capitalization, discount rate, dividends, regression analysis, capital structure, shares.
\end{abstract}

\section{Introduction}

An effective dividend policy is extremely important for a company in its quest to maximize the wealth of its shareholders. In recent decades, dividend policy has attracted the attention of financial analysts around the world. It has also been a source of controversy and the subject of intense theoretical and empirical research. The link between dividend policy and share prices remains one of the controversial aspects of dividend policy.

At the same time, despite the significant amount of research carried out, practically none of them concerned Russian companies and, in particular, the oil industry, so this work differs from previous studies in several respects. First, the analysis is fully focused on the Russian economy, which means that it takes into account its specific features. Secondly, the period covered by this study (2013-2019) is unique and largely covers the latest trends in the development of the market and economy. Finally, recent studies of dividend policy in Russia focus on the analysis of factors influencing the development of dividend policy and the size of dividend payments [1], rather than its impact on the value of the firm.

To achieve this goal, the following tasks were set: to study the results of theoretical and empirical studies of the problem under consideration, to review the literature on the topic, to analyze the legislative aspects, to conduct a regression analysis of the sample, to check

*Corresponding author: ivan-erx@yandex.ru 
the statistical significance of the model, to determine practical recommendations for using the analysis results.

\subsection{Concept of dividends and dividend policy}

In general, the concept of dividends (from the Latin word dividendum - what is to be divided) means the share of the company's net profit distributed among shareholders (participants) as a return on their investment in the company. They can be paid to shareholders either in cash (English cash dividend) or by new shares (English stock dividend).

A similar definition is given in article 43 of the Tax Code of the Russian Federation, however, in this definition, the key features are used to calculate the tax base, therefore it is separately specified that payments to shareholders (participants) of an organization in the form of transferring shares of the same organization into ownership are not dividends [2]. At the same time, Article 42 of the Federal Law "On Joint Stock Companies" states that dividends can be paid in money, and in cases stipulated by the charter of the company, other property [3]. Thus, if the company decides to pay dividends in shares, such payment is not taxed (which has been 13\% since 2015), since legally this is a simple change in the structure of the authorized capital (or its increase) (see Fig. 1).

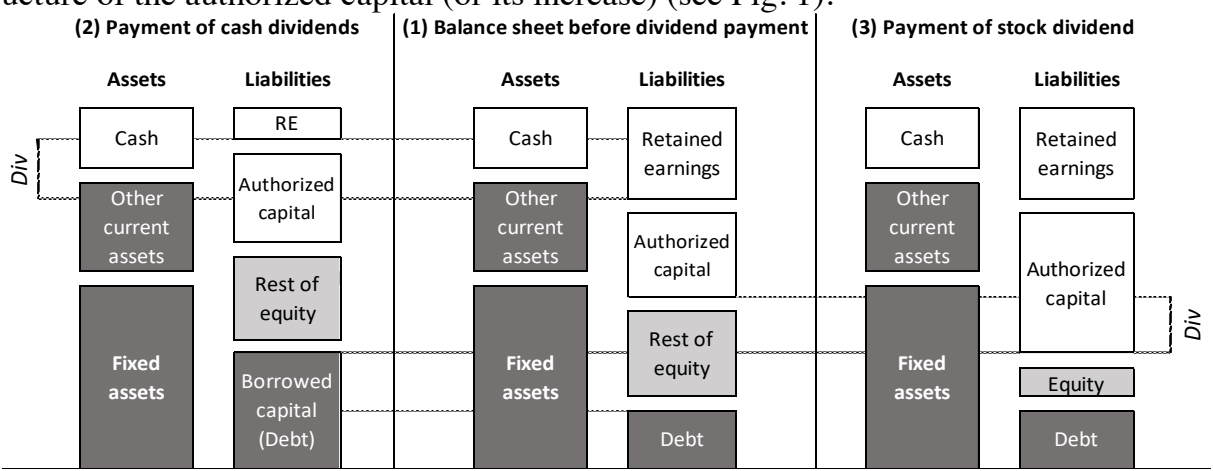

Fig. 1. Reflection of payment of dividends in the balance sheet

Source: Own processing.

In practice, dividends are not rarely paid in the form of shares. Archer Daniels Midland, an international agro-industrial corporation (ADM), sometimes called the "dividend aristocrat", has regularly paid dividends in shares of $5 \%$ of the number of shares held for more than 20 years [4].

The decision of the organization as to how much profit can be paid as dividends and how much should be retained by the firm is the task of the dividend policy.

\subsection{Market value of the company}

The value of the enterprise is broader than the concept of market capitalization, which reflects only the market value of equity (Formula 1).

$$
E V=M V_{\text {com }}+M V_{\text {pref }}+D-I_{\text {subsidiary }}-\text { Cash }
$$

where $M V_{\text {com }}$ - the market value of common shares

$M V_{\text {pref }}-$ market value of preferred shares

$D$ - market value of debt 


\section{$I_{\text {subsidiary }}$ - value of investments in associated companies [5]}

Cash is deducted because the total debt can be reduced (paid off) at the expense of cash and cash equivalents (Formula 2).

$$
\text { Net debt }=\text { total debt }- \text { cash and cash equivalents }
$$

All other things being equal, the dividend policy affects only the cost of equity. The market value of debt mainly includes loans that are not quoted on the stock exchange, are paid in full accordance with the agreement to a specific bank and are sold to them only in extreme cases. Bond loans, the value of which is obtained by discounting the expected cash flows of the bond to date using an appropriate discount rate, are debt securities traded in the bond market. Their value may change when dividends are declared, since they will demonstrate the company's solvency (in accordance with the signal theory of dividends), but only in the short term. In a study by J. Hanjinikolaus and A. Calay, for example, it is confirmed that with a decrease in dividend payments, bonds lost in value, i.e. they became less attractive, as did stocks. At the same time, in the opposite situation, the bonds remained unchanged.

At the same time, studies show that credit availability and cost are mainly influenced by "credit information" and legal regulations, as this reduces risks. This is supported by the results of Quoc Trung Tran, which conducted a regression analysis of a sample of 37,673 observations collected in 39 countries between 2013 and 2015, with the relationship being stronger in countries with strong regulations [6].

It is also assumed that if there is a relationship between the payment of dividends and the market value of borrowed capital, then it is reflected in the cost of equity, moreover, both managers and shareholders are guided by the cost of equity. Thus, when assessing the impact of dividend policy on the market value of a company, it is advisable to take into account the change in the value of equity capital only.

\subsection{Effectiveness of dividend policy}

The main source of financing for the organization's activities is its own capital, an important part of which is retained earnings. The payment of dividends reduces the volume of reinvested profits, therefore, the dividend policy affects the volume of own sources of financing and, indirectly, the volume of attracted debt capital. In other words, the payment of dividends, on the one hand, can increase the attractiveness of shares, but on the other hand, it will not allow increasing the book value of capital and, even worse, it will not provide an opportunity to invest these funds in profitable projects.

In this regard, there are still discussions in the scientific literature about the ability of the dividend policy to influence the value of shares and about the optimal size of the share of profit distributed among shareholders. A significant number of points of view and a large number of studies have accumulated, each of which confirms one or another opinion, but they are all based on several theories of dividend policy:

- The theory of the preference of dividends (Bird-in-the-hand theory)

- Tax differential theory

- Signal theory of dividends

- The theory of conformity of the dividend policy to the composition of shareholders or the theory of clientele (clientele theory)

- Classical dividend irrelevance theory 


\subsection{Theories of dividend policy}

The theory of the preference of dividends (bird-in-the-hand theory) is based on the fact that investors, proceeding from the principle of minimizing risk, always prefer current dividend payments to potential benefits in the future.

The positive effect on the market value is also explained by the fact that current income (paid in the form of dividends) is more expensive than income deferred for the future, due to its inherent risk [7] and it is not just about discounting. Since the amount of dividends paid indicates the stability and sustainability of the company's results, the minimum required shareholder return (discount rate) decreases, causing an increase in the present value of cash flows.

In addition, in some countries, due to legislation, shareholders prefer the payment of dividends to the reinvestment of profits due to the different tax rates on exchange rate gains and dividends [8].

This fact is taken into account by the tax differential theory, according to which, in order to take into account the impact of tax expenditures, Brennan (1970) adjusted the CAPM model to make the rate more attractive for companies with lower dividends (for the case when tax the rate on dividend yield is higher), thus weakening Miller and Modigliani's assumption that there are no taxes (see The Theory of Dividend Independence).

Despite extensive empirical research, this hypothesis does not appear to be supported by the data. Moreover, Poterba (1987) documented the stability of dividend payments during periods of extensive US tax changes [9].

Although the impact of taxes remains inconclusive, increasing attention is being paid to the problem of information asymmetry. Subsequent research by Watts (1973) and others has confirmed that the accrual of dividends increases the price of a stock, while a reduction in dividends tends to lower prices. Information asymmetry also made it possible to take into account the cost of paying dividends [10]. In addition, managers are often faced with weakened oversight in the event of a stable dividend payout, as high dividends can increase shareholder confidence in management.

Signaly theory pf dividents, built on these principles, asserts that when assessing the fundamental value (or assessing the attractiveness of shares by shareholders), significant information is carried by the change in the level of dividends - a signal that the company is on the rise and expects an increase in profits in the next periods.

If the amount of dividends is dictated from the outside, then, for example, in Russian practice [11], this measure in most cases has a negative effect on the value, since the political factor is involved.

The theory of conformity of dividend policy to the composition of shareholders or clientele theory challenges all previous provisions and argues that dividend policy is influenced by the interests of the majority of the company's shareholders, some of whom prefer the current yield, while others favor the growth of share prices in the future. In other words, the impact on value is a secondary concern.

Ciaran Driver, Anna Grosman, and Pasquale Scaramozzino show that investor pressure on businesses is more than just overseeing management activities (which have opposing interests according to agency theory). However, it is argued that such pressures arise in poorly performing financial markets and are responsible for the "increased appetite" for liquidity and short-term income [12].

The classical dividend irrelevance theory says that dividends do not affect the value of stocks. This position is substantiated by Merton Miller and Franco Modigliani in a theoretical article in 1961. They reasoned as follows. 
During each period, the firm determines its investment policy, attracts financing, pays dividends, which can be secured by new loans in the capital market (issue of shares) or by increasing borrowing. Proving the first theorem about the independence of the company's value from the financing structure, the authors conclude that two identical firms (with equal EBIT), differing only in the volume of borrowings, are worth the same [13].

At the same time, the first theorem does not take into account the effect of risk on investor behavior, because a company with a leverage due to the fact that $r$ (interest rate on loans) is lower than WACC, there is a lower minimum required return. The second theorem on the weighted average cost of capital proves the opposite. In other words, both the rate and the income are equal for both firms, which, in accordance with the income approach, gives equal value to the companies, which means that the value of the company is mainly determined not by the dividend policy and not the amount of borrowed funds, but by the efficiency of activities (profitability, etc.) [13].

Thus, in a perfect capital market, dividend policy matters only because it affects the ratio of the return on investment and the required rate of return (i.e. IRR> WACC). Therefore, the dividend policy should be based on the residual principle. The sequence of actions of the company's management should be as follows:

1) If investment projects provide a level of profitability that exceeds the required rate of return, then they are accepted.

2) Dividends are paid if not all profits are used to invest in these projects.

In other words, the reinvestment of profits increases the welfare (market value of the company) only if it is spent efficiently: if the generated income covers the cost of raising capital. In fact, the validity of MM's arguments is recognized by almost everyone, and the dispute is about whether taxes, emission costs and other market imperfections affect the situation. These assumptions are built and confirmed by some practical research.

\subsection{Foreign experience}

In the Russian economy, the capital market is less developed than the European or American, so the theory of Miller and Modigliani may not work in its pure form.

First of all, in Russia, as elsewhere, there is tax differentiation, although dividends on shares and income from their sale are taxed at an equal rate of $13 \%$ (for residents of the Russian Federation), the fact is that income tax on the sale of securities is paid in the moment money is withdrawn from the account, while dividends are taxed at the moment the money is credited to the account, even though they may be reinvested in shares. As a result, shareholders should choose not to receive dividends (all other things being equal).

Presumably, given the importance to the economy of the oil and gas sector, Russia is somewhat reminiscent of Nigeria, where some of the problems are most pronounced. From this point of view, the analysis of Nigeria's oil industry is of interest.

The article "The Impact of Dividend Policy on the Shareholders Value of Listed Firms in the Nigerian Petroleum Marketing Industry" (Alhaji Ali Tijjani, Mohd Norfian Alifiah and Gana Kafiya Wakil) assesses the impact of dividend policy on the value of Nigerian oil companies. Regression analysis of a sample of six firms listed on the Nigerian Stock Exchange (NSE) for the period 2008-2017 refutes the hypothesis that "dividend payments by oil firms in Nigeria do not significantly affect share prices."

The result showed a positive significant relationship between dividend policy and the market value of the firms in question. [14] This study confirms the literature on the relevance of dividends by Gordon (1962) and Walter (1963) and rejects Miller and Modigliani (1961), given that their underlying assumptions may not hold true in the Nigerian context. 
However, the authors explained this dependence by the weak protection of minority shareholders and the underdevelopment of the capital market, respectively, to analyze the situation in Russia, additional research is needed.

\section{Methodology}

The analysis methods used by the study include regression. The hypothesis being tested is the presence of the influence of dividend policy on the value of firms (market value of equity capital).

As a dependent variable $\left(y_{i}\right)$, capitalization in absolute terms or its growth rate can be taken (since its value varies quite strongly depending on the firm). The independent variables $\left(x_{i j}\right)$ under consideration include the factors mentioned in the first chapter, the influence of which is presumably the strongest: the amount of dividends (or dividend yield), the share of profit allocated to dividend payments, return on equity ROE, leverage $\left(\frac{D}{E}\right)$, as well as the Moscow Exchange's IMOEX index (since during recessions, as noted earlier, companies keep the amount of dividends at the same level).

\section{Results}

\subsection{Regression analysis of the largest companies}

As already mentioned, the founders of the classical dividend theory based their assumptions on some premises associated with a perfect capital market:

- free and equal accessibility of information for all investors, no transaction costs, rationality of shareholders' behavior

- guaranteed placement of additionally issued shares

Other theories are based on criticism of these premises, therefore, in order to get as close as possible to the conditions of a perfect market and to minimize the influence of other variables, it is advisable to consider the largest Russian companies in terms of capitalization, the so-called blue chips.

These are the most stable and liquid firms, so there is an opportunity to sell or buy a significant amount of shares of these companies at any time during a trading session on the stock exchange without a significant loss in price. In addition, a significant number of minority shareholders and investors ensure the rationality of the players' behavior, minimizing the impact of "deviations" of individual cases and irrational actions, and due to the fact that the largest companies are always in the spotlight, information spreads rather quickly and is practically equally accessible. The prominence and size of these issuers allows them to place additionally issued shares with virtually no loss.

In view of the above explanations, the 20 largest companies in terms of capitalization were selected (as of December 31, 2019) [15]. Data were obtained from firms' annual reports for the period 2013-2019. [16] (altogether 140 observations, see Table 1). Let's note right away that market capitalization is the total value of the company's shares currently in circulation (both common and preferred) [15]. 
Table 1. Summary table of random sample of empirical observations

\begin{tabular}{|c|c|c|c|c|c|c|c|c|}
\hline № & Ticker & Period & ROE & D/E & $\begin{array}{c}\text { Dividend } \\
\text { per share, } \\
\text { RUB }\end{array}$ & $\begin{array}{c}\begin{array}{c}\text { Change in } \\
\text { capitalization, } \\
\%\end{array} \\
\end{array}$ & $\begin{array}{c}\text { Capitalization, } \\
\text { rub. }\end{array}$ & $\begin{array}{c}\text { Dividend } \\
\text { yield, \% }\end{array}$ \\
\hline 1 & GASP & 31.12 .2013 & $12,1 \%$ & 0,39 & 7,20 & $-3,82 \%$ & 3286120325649 & $5,19 \%$ \\
\hline 2 & SBER & 31.12 .2013 & $19,2 \%$ & 8,68 & 3,20 & $9,12 \%$ & 2260945225920 & $3,06 \%$ \\
\hline$-1-$ & $-/-$ & $-1-$ & $-/-$ & $-1-$ & $-1-$ & $-/-$ & $-1-$ & $-1-$ \\
\hline 121 & GASP & 31.12 .2019 & $8,7 \%$ & 0,50 & 0,00 & $67,46 \%$ & 6077464231688 & $0,00 \%$ \\
\hline 122 & SBER & 31.12 .2019 & $20,4 \%$ & 5,68 & 18,70 & $36,51 \%$ & 5709855444600 & $7,07 \%$ \\
\hline 123 & ROSN & 31.12 .2019 & $15,6 \%$ & 1,51 & 33,41 & $5,29 \%$ & 4775538924340 & $7,41 \%$ \\
\hline 124 & LKOH & 31.12 .2019 & $15,8 \%$ & 0,41 & 192,00 & $17,82 \%$ & 4405472500000 & $3,12 \%$ \\
\hline 125 & NVTK & 31.12 .2019 & $53,0 \%$ & 0,21 & 32,33 & $11,72 \%$ & 3833639955600 & $2,56 \%$ \\
\hline 126 & GMKN & 31.12 .2019 & $139,2 \%$ & 3,54 & 1488,02 & $48,17 \%$ & 3050339795376 & $7,72 \%$ \\
\hline 127 & SIBN & 31.12 .2019 & $19,1 \%$ & 0,73 & 37,96 & $21,71 \%$ & 1994901823109 & $9,02 \%$ \\
\hline 128 & SNGS & 31.12 .2019 & $-0,4 \%$ & 0,18 & 0,00 & $67,04 \%$ & 2107381083926 & $0,00 \%$ \\
\hline 129 & TATN & 31.12 .2019 & $25,6 \%$ & 0,65 & 64,47 & $6,74 \%$ & 1776863479240 & $7,90 \%$ \\
\hline 130 & PLZL & 31.12 .2019 & $105,5 \%$ & 3,35 & 162,98 & $31,34 \%$ & 944878136366 & $2,32 \%$ \\
\hline 131 & YNDX & 31.12 .2019 & $4,9 \%$ & 0,27 & 0,00 & $40,43 \%$ & 791769254430 & $0,00 \%$ \\
\hline 132 & NLMK & 31.12 .2019 & $22,5 \%$ & 0,76 & 17,36 & $-9,02 \%$ & 858829463492 & $12,11 \%$ \\
\hline 133 & CHMF & 31.12 .2019 & $50,8 \%$ & 1,36 & 115,88 & $-0,13 \%$ & 788293259060 & $12,31 \%$ \\
\hline 134 & MTSS & 31.12 .2019 & $151,4 \%$ & 21,64 & 42,50 & $35,06 \%$ & 641980080969 & $13,23 \%$ \\
\hline 135 & ALRS & 31.12 .2019 & $24,7 \%$ & 0,69 & 2,63 & $-13,79 \%$ & 624475435768 & $3,10 \%$ \\
\hline 136 & VTBR & 31.12 .2019 & $12,2 \%$ & 8,38 & 0,00 & $35,36 \%$ & 596573717758 & $0,00 \%$ \\
\hline 137 & IRAO & 31.12 .2019 & $14,8 \%$ & 0,36 & 0,20 & $29,35 \%$ & 525393000000 & $3,90 \%$ \\
\hline 138 & MAGN & 31.12 .2019 & $15,5 \%$ & 0,50 & 3,83 & $-1,84 \%$ & 471165624450 & $9,08 \%$ \\
\hline 139 & POLY & 31.12 .2019 & $25,1 \%$ & 1,20 & 0,82 & $35,84 \%$ & 454483915087 & $0,08 \%$ \\
\hline 140 & MGNT & 31.12 .2019 & $5,1 \%$ & 4,03 & 304,19 & $-2,44 \%$ & 349861681715 & $8,86 \%$ \\
\hline \multicolumn{3}{|c|}{ Standard deviation } & $45 \%$ & 3,50 & 254,25 & $38,23 \%$ & 1293895108782 & $4,11 \%$ \\
\hline \multicolumn{3}{|c|}{ The coefficient of variation } & $232,8 \%$ & $169 \%$ & $275,1 \%$ & $204,8 \%$ & $97,1 \%$ & $83,5 \%$ \\
\hline
\end{tabular}

Source: Own processing on the basis of reporting data and information from the Moscow Exchange website.

To find the most accurate regression model, consider several options for the arrangement of variables:

1. $y_{i}$ - capitalization, rub.; $x_{i 1}-\mathrm{ROE} ; x_{i 2}-\frac{D}{E} ; x_{i 3}$ - dividend per share, rub.

2. $y_{i}$ - capitalization growth, $\% ; x_{i 1}-\mathrm{ROE} ; x_{i 2}-\frac{D}{E} ; x_{i 3}$ - dividend per share, rub.

3. $y_{i}$ - capitalization growth, $\% ; x_{i 1}-\mathrm{ROE} ; x_{i 2}-\frac{D}{E} ; x_{i 3}$ - dividend yield, $\%$

4. $y_{i}$-capitalization, руб.; $x_{i 1}-\mathrm{ROE} ; x_{i 2}-\frac{D}{E} ; x_{i 3}$ - dividend yield, $\%$

The multiple linear regression model for individual observations in general looks like (formula 3):

$$
y_{i}=\beta_{0}+\beta_{1} R O E_{i}+\beta_{2}\left(\frac{D}{E}\right)_{i}+\beta_{3} D i v_{i}+\varepsilon_{i}
$$

The results of the given calculations show that all equations describing the dependence are statistically insignificant (see Table 2). In addition, checking the significance of the coefficients shows that they are all statistically close to zero, therefore, there is no statistical relationship between the explained variable $\mathrm{Y}$ and the explanatory variables $\left.X_{j}\right)(j=1,2,3)$. This may be due to the fact that there are other factors affecting the cost. On the other hand, the results obtained may be due to significant differences between the companies in question. The considered firms, although quite similar in size, still operate in different industries, which affects financial results, profitability of production, and other indicators.

It is worth noting that in those models where $R^{2}$ is higher (in models $1,2,3$ ), the coefficients before $x_{3}$, showing the relationship between this variable and the effective 
factor $y_{1}$, are the lowest relative to other coefficients. In model 2 and 3, they are 0 (or very close to it). In model 4 , the coefficient is negative. Analysis of factors using paired regression (the relationship between capitalization and dividends) does not change the result, this model is also statistically insignificant.

In other words, as was proved by Miller and Modigliani, the market value of companies depends mainly on market conditions, the state of the economy, management efficiency, profitability of production, and other features, and not on dividend policy.

At the same time, this cannot yet be asserted, since it is likely that the low quality of the model is caused by strong differences between the companies. This is confirmed by the too large value of the coefficient of variation. It is found by the following formula (formula 4):

$$
V=\frac{\sigma}{\bar{x}} \cdot 100 \%
$$

$$
\sigma \text { - standard deviation, } \bar{x}-\text { mean }
$$

This coefficient shows the degree of variability in relation to the sample mean [17], in other words, how much the $x_{i}$ deviates from the mean among the observed observations. In the sample under consideration, some indicators deviate from the average by more than two times (see Table 1, row "Coefficient of variation").

\begin{tabular}{|c|c|c|c|c|c|c|}
\hline № & $\begin{array}{l}\text { Parameter } \\
\text { estimates }\end{array}$ & t-statistics & $\begin{array}{c}\text { Statistical } \\
\text { significanc } \\
\text { e } b_{i}(t= \\
1,98)\end{array}$ & & $\begin{array}{c}\text { ecking the Significan } \\
\text { Equation }\end{array}$ & an \\
\hline \multirow[b]{4}{*}{1} & b0 & 1259053868517 & 9,469 & Yes & $R^{2}$ & 0,0128 \\
\hline & $\mathrm{b} 1$ & 47984848897 & $-0,160$ & No & $F$ & 0,5875 \\
\hline & $\mathrm{b} 2$ & 14810214675 & 0,401 & No & $F_{\alpha ; m ; n-m-1}$ & 2,6712 \\
\hline & b3 & 561642082 & 1,232 & No & Equation significance & No \\
\hline \multirow[b]{4}{*}{2} & b0 & 0,2013 & 5,107 & Yes & $R^{2}$ & 0,0064 \\
\hline & b1 & $-0,0199$ & $-0,224$ & No & $F$ & 0,2926 \\
\hline & b2 & $-0,0070$ & $-0,641$ & No & $F_{\alpha ; m ; n-m-1}$ & 2,6712 \\
\hline & b3 & 0,0000 & 0,302 & No & Equation significance & No \\
\hline \multirow[b]{4}{*}{3} & b0 & 0,2013 & 4,270 & Yes & $R^{2}$ & 0,0088 \\
\hline & b1 & $-0,0199$ & 0,022 & No & $F$ & 0,4013 \\
\hline & $\mathrm{b} 2$ & $-0,0070$ & $-0,714$ & No & $F_{\alpha ; m ; n-m-1}$ & 2,6712 \\
\hline & b3 & 0,0000 & $-0,645$ & No & Equation significance & No \\
\hline \multirow[b]{4}{*}{4} & b0 & 0,2284 & 6,784 & Yes & $R^{2}$ & 0,0039 \\
\hline & $\mathrm{b} 1$ & 0,0019 & 0,088 & No & $F$ & 0,1768 \\
\hline & $\mathrm{b} 2$ & $-0,0078$ & 0,289 & No & $F_{\alpha ; m ; n-m-1}$ & 2,6712 \\
\hline & b3 & $-0,5300$ & 0,536 & No & Equation significance & No \\
\hline
\end{tabular}

Table 2. Regression analysis calculation table

Source: Own processing.

Thus, it is premature to conclude that the relationship between dividends and changes in the company's value is insignificant. To minimize the impact of differences in company characteristics, it is advisable to consider the largest companies in the same industry, for example, oil.

\subsection{Analysis of Russian companies in the oil and gas sector}

Based on the same rating of the largest companies on the Moscow Exchange website, companies engaged in the production and processing of oil were selected: Rosneft (ROSN), LUKOIL (LKOH), Gazprom Neft (SIBN), Surgutneftegaz "(SNGS), Tatneft (TATN). 
All collected data from the reports and from the Moscow Exchange website are collected in Table 3: ROE is the ratio of net profit to equity, $\mathbf{D} / \mathbf{E}$ is borrowed funds on equity, Dividend yield $=$ Dividend $/$ market value of one share $* 100 \%$, IMOEX - the value of the Moscow Exchange index at the end of the year and the others. You can see that the range of values has greatly decreased - the coefficients of variation are lower.

The considered model looks as follows (formula 5):

$$
y_{i}=b_{0}+b_{1} R O E_{i}+b_{2}\left(\frac{D}{E}\right)_{i}+b_{3} \operatorname{Div}_{i}+b_{4} \operatorname{Div}(\%)_{i}+b_{5} d_{i}+b_{6} I_{M O E X}+e_{i}
$$

where $b_{0}, b_{1}, b_{2}, b_{3}, b_{4}, b_{5}, b_{6}$-empirical regression coefficients (estimates of the parameters $\beta_{0}, \ldots, \beta_{6} . e_{i}$-error terms (deviation estimates $\varepsilon_{i}$ ). The results of the calculations are shown in Table 4 .

Table 3. Calculation table of indicators $\left(x_{i j}\right.$ and $\left.y_{i}\right)$

\begin{tabular}{|c|c|c|c|c|c|c|c|c|c|}
\hline № & Ticker & Period & ROE & $\mathbf{D} / \mathbf{E}$ & $\begin{array}{c}\text { Dividend } \\
\text { per } \\
\text { share, } \\
\text { rub. }\end{array}$ & $\begin{array}{l}\text { Dividend } \\
\text { yield, \% }\end{array}$ & $\begin{array}{c}\text { Share of } \\
\text { dividends } \\
\text { in Net } \\
\text { profit }\end{array}$ & IMOEX & $\begin{array}{l}\text { Capit- } \\
\text { n, } \\
\text { billion } \\
\text { rubles }\end{array}$ \\
\hline 1 & ROSN & 31.12 .2013 & $17,4 \%$ & 1,38 & 12,85 & $5,14 \%$ & $24,72 \%$ & 3045,87 & 2650,0 \\
\hline 2 & LKOH & 31.12 .2013 & $9,9 \%$ & 0,39 & 110,00 & $4,56 \%$ & $31,50 \%$ & 3045,87 & 1723,6 \\
\hline 3 & SIBN & 31.12 .2013 & $18,7 \%$ & 0,57 & 9,38 & $6,36 \%$ & $23,82 \%$ & 3045,87 & 699,8 \\
\hline 4 & SNGS & 31.12 .2013 & $13,5 \%$ & 0,16 & 0,60 & $1,77 \%$ & $7,68 \%$ & 3045,87 & 1209,1 \\
\hline 5 & TATN & 31.12 .2013 & $15,5 \%$ & 0,34 & 8,23 & $3,82 \%$ & $22,89 \%$ & 3045,87 & 468,9 \\
\hline 6 & ROSN & 31.12 .2014 & $12,1 \%$ & 2,03 & 8,21 & $4,20 \%$ & $24,86 \%$ & 2369,33 & 2071,4 \\
\hline$-/-$ & $-/-$ & $-/-$ & $-/-$ & $-1-$ & $-/-$ & $-/-$ & $-/-$ & $-1-$ & $-/-$ \\
\hline 30 & TATN & 31.12 .2018 & $27,2 \%$ & 0,55 & 84,91 & $11,11 \%$ & $87,45 \%$ & 1396,61 & 1664,7 \\
\hline 31 & ROSN & 31.12 .2019 & $15,6 \%$ & 1,51 & 33,41 & $7,41 \%$ & $43,99 \%$ & 1504,08 & 4775,5 \\
\hline 32 & LKOH & 31.12 .2019 & $15,8 \%$ & 0,41 & 192,00 & $3,12 \%$ & $21,38 \%$ & 1504,08 & 4405,5 \\
\hline 33 & SIBN & 31.12 .2019 & $19,1 \%$ & 0,73 & 37,96 & $9,02 \%$ & $42,64 \%$ & 1504,08 & 1994,9 \\
\hline 34 & SNGS & 31.12 .2019 & $-0,4 \%$ & 0,18 & 0,00 & $0,00 \%$ & $0,00 \%$ & 1504,08 & 2107,4 \\
\hline 35 & TATN & 31.12 .2019 & $25,6 \%$ & 0,65 & 64,47 & $7,90 \%$ & $72,85 \%$ & 1504,08 & 1776,9 \\
\hline \multicolumn{3}{|c|}{ Standard deviation } & $7 \%$ & 0,62 & 72,94 & $2,47 \%$ & $22,87 \%$ & 533,89 & 1212,3 \\
\hline \multicolumn{3}{|c|}{ The coefficient of variation } & $47,7 \%$ & $83,6 \%$ & $144,8 \%$ & $52,1 \%$ & $77,1 \%$ & $25,92 \%$ & $62,0 \%$ \\
\hline
\end{tabular}

Source: Own processing based on reporting data and information from the Moscow Exchange website.

In the model under consideration, the coefficient $\mathrm{R}^{2}=0,7110$, which indicates good predictive properties of the equation. Hypothesis $H_{0}\left(\mathrm{R}^{2}=0\right)$ is rejected in favor of the alternative hypothesis, since $F>F_{\alpha ; m ; n-m-1}$, in other words, the equation is statistically significant. Parameters $b_{2}$ (financial leverage), $b_{3}$ (dividend per share) and $b_{6}$ (Moscow Exchange index) are significant, since $\left|t_{b_{i}}\right|>t=2,045$, which indicates a positive linear relationship between capitalization and the amount of financial leverage and dividend per share.

Thus, Theorem 3 (on the ratio of prices of a company with $100 \%$ equity capital and a company with debt obligations), taking into account taxes, was confirmed: with an increase in the size of loans $\left(\frac{D}{E}\right)$, the value of the company also increases.

It should be noted that the influence of the dividend yield on capitalization is negative. This is probably due to the fact that after the payment of dividends there are drawdowns, the value of which is equal to the size of the dividend per share. These downturns, or dividend gaps, take some time to recover, and the larger the drawdown, the longer it takes for the price to recover, which is certainly reflected in the equity market value. However, after the corresponding calculations, the parameter $b_{4}$ turned out to be statistically insignificant, therefore, there is no effect of this indicator on capitalization. 
An interesting fact is that during a market fall (a decrease in the IMOEX index), the capitalization of the companies in question is growing, perhaps this is due to the fact that investors view these companies as a more stable investment object during the crisis.

Table 4. Checking the Significance of the Regression Equation

\begin{tabular}{|c|c|c|c|c|c|}
\hline \multicolumn{2}{|c|}{$\begin{array}{c}\text { Parameter } \\
\text { estimates }\end{array}$} & \multirow{2}{*}{$\begin{array}{r}\begin{array}{c}\text { t- } \\
\text { statistics }\end{array} \\
3.7407\end{array}$} & \multirow{2}{*}{$\begin{array}{c}\begin{array}{c}\text { Statistical significance } \boldsymbol{b}_{\boldsymbol{i}} \\
(\boldsymbol{t}=\mathbf{2 , 0 4 8})\end{array} \\
\text { Yes }\end{array}$} & \multicolumn{2}{|c|}{$\begin{array}{c}\text { Проверка значимости } \\
\text { уравнения }\end{array}$} \\
\hline b0 & 2588,645 & & & $R^{2}$ & 0,7110 \\
\hline b1 & 1274,748 & 0,5768 & No & $F$ & 11,4838 \\
\hline $\mathrm{b} 2$ & 1373,949 & 5,9139 & Yes & $F_{\text {test }}$ & 2,4453 \\
\hline b3 & 9,540 & 4,8684 & Yes & Equation significance & Yes \\
\hline $\mathrm{b} 4$ & $-14090,53$ & $-1,6121$ & No & \multirow{3}{*}{\multicolumn{2}{|c|}{$-/-$}} \\
\hline b5 & $-417,913$ & $-0,4404$ & No & & \\
\hline b6 & $-0,738$ & $-3,0311$ & Yes & & \\
\hline
\end{tabular}

Source: Own processing.

Thus, for the companies under consideration, there is a positive relationship between the size of the dividend per share and the market value of capital. The implication is that the payment of dividends allows shareholders to get a return on their investment in the company, while potential investors are inspired by the ownership of shares in the companies. Investors are responding to the dividend declaration as a sign of financial prosperity, removing uncertainty about firms' ability to operate profitably. However, we must not forget that the amount of dividends must be reasonable; it is good if the company allocates "extra" funds for dividends, i.e. those that did not go to unprofitable projects. Shareholders usually respond favorably when companies distribute excess money instead of "wasting it on unprofitable projects." [4].

Table 5. Dynamics of the amount of dividend per share and capitalization, 2011-2019

\begin{tabular}{|r|l|c|c|c|}
\hline \multicolumn{1}{|c|}{ № } & Ticker & Period & Dividend per share & Capitalization, billion rubles \\
\hline 1 & LKOH & 31.12 .2011 & 75 & 1445,5 \\
\hline 2 & LKOH & 31.12 .2012 & 90 & 1706,1 \\
\hline 3 & LKOH & 31.12 .2013 & 110 & 1723,6 \\
\hline 4 & LKOH & 31.12 .2014 & 154 & 1886,0 \\
\hline 5 & LKOH & 31.12 .2015 & 177 & 2001,0 \\
\hline 6 & LKOH & 31.12 .2016 & 195 & 2916,2 \\
\hline 7 & LKOH & 31.12 .2017 & 215 & 2823,4 \\
\hline 8 & LKOH & 31.12 .2018 & 250 & 3739,1 \\
\hline 9 & LKOH & 31.12 .2019 & 192 & 4405,5 \\
\hline \multicolumn{2}{|l|}{ Coefandard deviation } & 59,46 & 1025,46 \\
\hline
\end{tabular}

Source: Own processing.

\subsection{Assessment of the impact of dividend policy on the market value of PJSC "Lukoil"}

Lukoil is one of the few private companies with minimal government influence on policy making. An interesting fact is that Lukoil adheres to the policy that Miller and Modigliani spoke about: the total amount of dividends on outstanding shares minus shares held by LUKOIL Group entities is at least $100 \%$ of the adjusted free cash flow, which is defined as net cash. received from operating activities, net of capital expenditures, interest paid, repayment of lease liabilities, and expenses for the acquisition of shares in LUKOIL. In other words, the funds remaining after their distribution to profitable projects (for which 
NPV $>0$ ) go to dividend payments. Thus, the analysis of the dependence of capitalization on dividend payments for this company is of considerable interest.

The results of evaluating the relationship between dividend per share and capitalization confirm a positive relationship, however, it should be remembered that they give a result if certain rules are observed: dividends must be paid on a leftover basis. The equation and coefficient $b_{1}$, reflecting the relationship between the factors under consideration, are statistically significant.

Table 6. Checking the Significance of Equation and parameters

\begin{tabular}{|c|c|c|c|c|c|}
\hline \multicolumn{2}{|c|}{$\begin{array}{c}\text { Parameter } \\
\text { estimates }\end{array}$} & $\begin{array}{c}\text { t- } \\
\text { statistics }\end{array}$ & $\begin{array}{c}\text { Statistical significance } \boldsymbol{b}_{\boldsymbol{i}}(\boldsymbol{t} \\
\mathbf{2}, \mathbf{0 4 5})\end{array}$ & \multicolumn{2}{c|}{$\begin{array}{c}\text { Checking the Significance of an } \\
\text { Equation }\end{array}$} \\
\hline b0 & 318,445 & 0,4617 & No & $R^{2}$ & 0,6189 \\
\hline \multirow{2}{*}{ b1 } & 13,567 & 3,3718 & \multirow{2}{*}{ Yes } & $F$ & 11,3690 \\
\cline { 4 - 6 } & & & $F_{\text {test }}$ & 3,6767 \\
\hline
\end{tabular}

Source: Own processing.

To assess the long-term impact on capitalization, you can consider a regression model with a time lag, i.e. "Shift" the variable $x_{i}$ (dividend per share) by several years. The results of this bias are shown in Table 7.

Table 7. Checking the significance of the equation and coefficients with a time lag

\begin{tabular}{|c|c|c|c|c|c|c|}
\hline $\begin{array}{c}\text { Lag, } \\
\text { years }\end{array}$ & \multicolumn{2}{|c|}{$\begin{array}{c}\text { Parameter } \\
\text { estimates }\end{array}$} & $\begin{array}{c}\mathbf{t}- \\
\text { statistics }\end{array}$ & $\begin{array}{c}\text { Statistical significance } \\
\boldsymbol{b}_{\boldsymbol{i}}(\boldsymbol{t}=\mathbf{2 , 3 6 4 6})\end{array}$ & \multicolumn{2}{c|}{$\begin{array}{c}\text { Checking the Significance of } \\
\text { an Equation }\end{array}$} \\
\hline \multirow{2}{*}{1} & b0 & 383,706 & 1,3027 & No & $R^{2}$ & 0,8987 \\
\cline { 2 - 7 } & b1 & 14,485 & 7,8808 & Yes & Equation significance & Yes \\
\hline \multirow{2}{*}{3} & b0 & 616,036 & 2,8054 & Yes & $R^{2}$ & 0,9299 \\
\cline { 2 - 7 } & b1 & 17,778 & 9,6390 & Yes & Equation significance & Yes \\
\hline \multirow{2}{*}{5} & b0 & 585,500 & 2,3474 & No & $R^{2}$ & 0,9479 \\
\cline { 2 - 7 } & b1 & 26,096 & 9,5421 & Yes & Equation significance & Yes \\
\hline
\end{tabular}

Source: Own processing.

Thus, the larger the "offset", the higher $\mathrm{R}^{2}$, i.e. the quality of the model, which suggests that dividends can play a role even after a few years. At the same time, this is true only for Lukoil, other companies may have different results.

\section{Conclusion}

Thanks to statistical data and an extensive methodological base of the study, an analysis was made of the influence of dividend policy on the market value of the company. Based on the main results of the study, the following conclusions were made

The payment of dividends by oil companies in Russia has a positive effect on the price of their shares. In addition, the theorem on the growth of the firm's value with an increase in financial leverage was confirmed, which is explained by the effect of the tax shield.

The effect of stable dividend payments on capitalization growth in the following periods was confirmed. So, using the example of observations for the period 2011-2019 for the indicators of Lukoil, an increase in the accuracy of the explanatory model, taking into account the time effect, was statistically revealed.

In addition, using the example of Lukoil, it is shown that despite the positive relationship between dividends and growth in value, the optimal dividend policy is to pay 
dividends on a residual basis - first of all, it is necessary to pay attention to rational investments. Exactly as described in the conclusions of Miller and Modigliani.

At the same time, the study confirms the arguments that dividend policy, when adhering to the listed rules, positively affects the value of shares, as argued in the work of Lintner (1956) and Gordon (1962).

The management of companies engaged in oil production and refining must first of all effectively invest retained earnings, and not withhold the remaining funds, but direct them to dividends or to buy back shares. This is the most preferred policy as it is usually perceived favorably by shareholders.

\section{References}

1. A. Abramov, A. Radygin, M. Chernova, R. Entov, The "dividend puzzle" and the Russian stock market. Part 2. Voprosy Ekonomiki, 2020(2), 59-85 (2020)

2. "Налоговый кодекс Российской Федерации (часть первая)" от 31.07.1998 N 146Ф3 (ред. от 01.04.2020) НК РФ Статья 43. Дивиденды и проценты [online], Available

at: http://www.consultant.ru/document/cons_doc_LAW_19671/fc207b30c9a64882be5319 27d7fbe7053769d6ca/ (10.05.2020)

3. Федеральный закон от 26.12.1995 N 208-Ф3 (ред. от 04.11.2019, с изм. от 07.04.2020) "Об акционерных обществах" (с изм. и доп., вступ. в силу с 01.01.2020) Статья 42. Порядок выплаты обществом дивидендов [online], Available http://www.consultant.ru/document/cons_doc_LAW_8743/9f4fbb73c39e25049b6c7c9 8bbbec1b66f83a9f2/ (10.05.2020)

4. R. Breyli, S. Mayers, Principles of corporate finance. ЗАО «Олимп-Бизнес», Moscow (2008)

5. Enterprise value [online], Available at: https://en.wikipedia.org/wiki/Enterprise_value (10.05.2020)

6. Quoc Trung Tran, Creditors and dividend policy: Reputation building versus debt covenant. European Research on Management and Business Economics 25( 3) (2019)

7. Теория независимости (иррелевантности) дивидендов [online], Available at: https://studme.org/263776/finansy/teoriya_nezavisimosti_irrelevantnosti_dividendov (2020)

8. М. Эскиндаров, М. Федотова, Корпоративные финансы; под ред. М.А. Эскиндарова, М.А. Федотовой. - Москва : КНОРУС (2020)

9. V. Aivazian, L. Booth, S. Cleary, Dividend policy and the organization of capital markets. Journal of Multinational Financial Management. 13 (2) (2003)

10. R. Watts, The information component of dividends. Journal of Business 46, 191/211 (1973)

11. РБК. Путин одобрил выплату госкомпаниями дивидендов в $50 \%$ от прибыли [online], Available at: https://www.rbc.ru/economics/27/04/2017/59020eaa9a794712f125072c (2020)

12. C. Driver, A. Grosman, P. Scaramozzino, Dividend policy and investor pressure. Economic Modelling [online], Available at: https://ez.el.fa.ru:2052/science/article/pii/S0264999318309623 (2020)

13. Modigliani-Miller Theorem [online], Available at: http://faculty.haas.berkeley.edu/parlour/teaching/corp_intro.pdf (2020) 
14. A.Tijjani, M. Alifiah, G.Wakil, The Impact of Dividend Policy on the Shareholders Value of Listed Firms in the Nigerian Petroleum Marketing Industry. International Journal of Recent Technology and Engineering (IJRTE) ISSN: 2277-3878, 8 (2S9) (2019)

15. Московская биржа. Рыночная капитализация [online], Available at: https://www.moex.com/s26 (2020)

16. Conomy. Эмитенты [online], Available at: https://www.conomy.ru/search (2020)

17. Коэффициент вариации [online],

Available at: https://ru.wikipedia.org/wiki/Коэффициент_вариации (2020) 